\title{
Serum Dopamine-Beta-Hydroxylase Activity in Women Occupationally Exposed to Carbon Disulphide
}

\author{
Key words: Occupational exposure - Viscose rayon female workers - Carbon
} disulphide - Serum dopamine-beta-hydroxylase

Occupational exposure to carbon disulphide $\left(\mathrm{CS}_{2}\right)$ vapor may result in various toxic manifestations. ${ }^{1,2)}$ Because catecholamine involvement may be a common factor in cardiovascular, neurological and psychiatric manifestations of $\mathrm{CS}_{2}$ intoxication, catecholamine metabolism seemed a natural target in the investigation of $\mathrm{CS}_{2}$ toxicity. Neurochemical investigations in rats have indicated that $\mathrm{CS}_{2}$ exposure results in an increase of dopamine content in brain and adrenals and in a decrease of brain noradrenaline concentration..$^{3,4)}$ These findings suggested that $\mathrm{CS}_{2}$ inhibits the activity of tissue dopamine-beta-hydroxylase (DBH). In fact, inhibition of DBH by $\mathrm{CS}_{2}$ was demonstrated later in chromaffine granule preparations ${ }^{5)}$ and has been also confirmed in vivo in rat adrenals. ${ }^{6}$ )

To our knowledge the influence of $\mathrm{CS}_{2}$ exposure on blood $\mathrm{DBH}$ activity has not yet been studied. In the present paper the effect of $\mathrm{CS}_{2}$ on serum DBH activity was investigated in female viscose rayon workers exposed to 5-6 ppm $\mathrm{CS}_{2}{ }^{*}$ in their workplace.

The subjects in our study were 63 female viscose rayon workers (mean age 36.9 ; range 19-54) and 28 unexposed to $\mathrm{CS}_{2}$ women employed in garment factory (control group: mean age 31.3; range 18-47). Consent was obtained from each woman after informing her of the purpose and nature of the study. All subjects were healthy and no subject was taking any medication for at least two weeks before the study. Selected for the study viscose rayon workers were divided into seven groups of nine subjects according to duration of occupational exposure to $\mathrm{CS}_{2}$ (Table 1).

All subjects reported to the laboratory on day 9 after the onset of menstrual flow in the morning (between 8 a.m. and 9 a.m.) after a light breakfast. They avoided coffee and smoking that morning. Half an hour before and during blood sampling for the determination of serum DBH activity the subjects were seated. Blood samples were collected into chilled glass tubes from an antecubital vein. The serum was separated by centrifugation at $4{ }^{\circ} \mathrm{C}$ and stored frozen at $-20^{\circ} \mathrm{C}$ until assayed. DBH activity of serum $(20 \mu \mathrm{l}$ aliquots $)$ was assayed in duplicate by the spectrophotometric method described by Nagatsu and Udenfriend ${ }^{7)}$ using tyramine as substrate.

In an additional study of ten serum samples taken from the $\mathrm{CS}_{2}$ exposed workers, copper sulphate has been added to the standard incubation mixture

\footnotetext{
* Value lower than the Polish Ministry of Labour permissible limit of $8 \mathrm{ppm}$ for $\mathrm{CS}_{2}$
} 
Table 1. Duration of exposure to $\mathrm{CS}_{2}$ and age (years) of the subjects.

\begin{tabular}{rcc}
\hline Group & Duration of exposure & Age (mean; range) \\
\hline I & 6 months & $25.6 ; 19-39$ \\
II & 1 year & $30.8 ; 21--46$ \\
III & 5 years & $36.4 ; 22-50$ \\
IV & 10 years & $32.4 ; 28-37$ \\
V & 15 years & $37.7 ; 32-45$ \\
VI & 20 years & $45.3 ; 39-49$ \\
VII & above 20 years & $50.0 ; 42-54$ \\
\hline
\end{tabular}

Table 2. Length of employment, age (years) and DBH activity in serum (nmol $\mathrm{min}^{-1} \mathrm{ml}^{-1}$ ) of control subjects.

\begin{tabular}{|c|c|c|}
\hline Duration of employment & $\begin{array}{c}\text { Age } \\
(\text { mean } \pm S E)\end{array}$ & $\begin{array}{l}\text { Serum } \mathrm{DBH} \text { activity } \\
(\text { mean } \pm \mathrm{SE})\end{array}$ \\
\hline $6 \underset{\mathrm{n}=4}{\text { months }}$ & $18.8 \pm 0.3$ & $42.65 \pm 6.54$ \\
\hline $1 \underset{n=4}{\text { year }}$ & $26.5 \pm 5.9$ & $45.11 \pm 10.32$ \\
\hline $5 \begin{array}{c}\text { years } \\
n=4\end{array}$ & $26.0 \pm 3.7$ & $43.66 \pm 4.79$ \\
\hline $10 \begin{array}{l}\text { years } \\
n=4\end{array}$ & $32.3 \pm 2.8$ & $29.58 \pm 4.73$ \\
\hline $15 \begin{array}{l}\text { years } \\
\mathrm{n}=4\end{array}$ & $34.3 \pm 1.7$ & $36.91 \pm 8.49$ \\
\hline $20 \begin{array}{l}\text { years } \\
\mathrm{n}=4\end{array}$ & $38.5 \pm 0.5$ & $39.37 \pm 2.10$ \\
\hline $\begin{array}{c}\text { above } 20 \text { years } \\
n=4\end{array}$ & $43.2 \pm 2.0$ & $30.59 \pm 7.30$ \\
\hline $\begin{array}{l}\text { Mean of the all control subjects } \\
n=28\end{array}$ & $31.3 \pm 1.8$ & $38.27 \pm 2.51$ \\
\hline
\end{tabular}

( $1 \mu \mathrm{mol} / \mathrm{l}$, final concentration) in order to eliminate a possible inhibitory effect of copper chelators (like the dithiocarbamate-type metabolites of $\mathrm{CS}_{2}$ ) on $\mathrm{DBH}$ activity.

The statistical analysis was performed using Student's $t$ test or paired $t$ test. $\mathrm{P}>0.05$ was regarded as statistically insignificant.

Table 2 shows the data concerning the control subjects. It can be seen that age and duration of employment do not influence the serum DBH activity in the women unexposed to $\mathrm{CS}_{2}$. For this reason the mean value of serum DBH activity found in the all control women was used to further calculations.

The distributions and mean serum DBH activities of the women exposed to $\mathrm{CS}_{2}$ and of the control ones are shown in Fig. 1. The mean DBH activities of the groups I and II, including the women shortly exposed to $\mathrm{CS}_{2}$ were not different from that of the control group. Similarly, no significant difference was found between the mean enzyme activity in the women exposed to $\mathrm{CS}_{2}$ for 15 years (group V) and in the control ones. The mean DBH activities in the women with $5,10,20$ and above 20 years of exposure to $\mathrm{CS}_{2}$ (groups III, IV, VI and VII, 


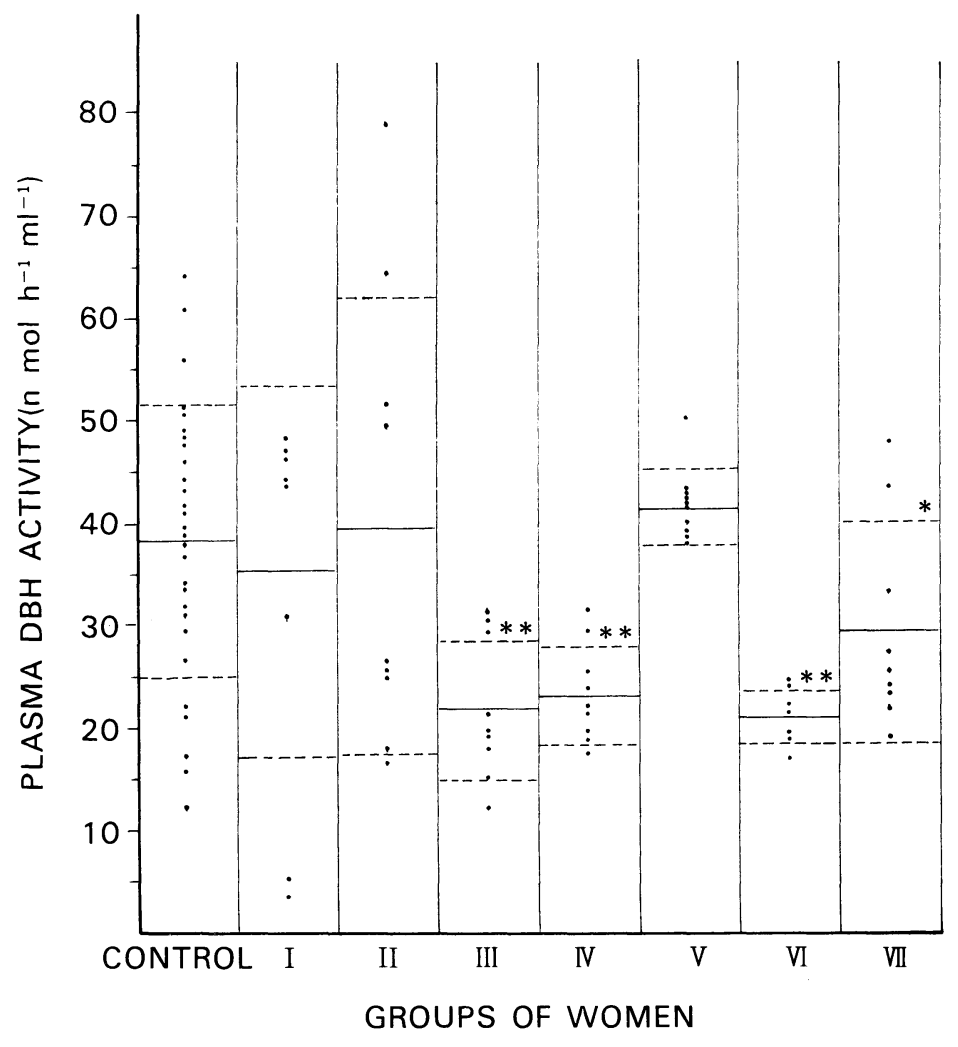

Fig. 1 Distributions of serum DBH activity in women occupationally exposed to $\mathrm{CS}_{2}$. The horizontal lines represent the mean \pm SEM, groups I-VII-duration of exposure to $\mathrm{CS}_{2}: 6$ months, $1,5,10,15,20$ and above 20 years, $* * \mathbf{p}<0.001, * \mathbf{p}<0.05$.

respectively) were significantly lower than that of the control group $(\mathrm{p}<0.001$ for groups III, IV, VI and $\mathrm{p}<0.05$ for group VII).

Addition of copper sulphate solution to the standard incubation mixture produced a clear decrease of DBH activity in ten serum samples taken from the $\mathrm{CS}_{2}$ exposed women from $28.21 \pm 3.21$ to $23.23 \pm 3.03$ (mean $\pm S E$ ). The decrement of the enzyme activity was statistically significant $(\mathrm{p}<0.001)$ and its percentage ranged from 13.2 to $31.6 \%$ with mean of $17.6 \pm 1.9 \%$ in the ten samples.

The present study showed that the occupational exposure to low concentrations of $\mathrm{CS}_{2}$ influences serum DBH activity in the women. The mean enzyme activities in the women exposed to $\mathrm{CS}_{2}$ for $5,10,20$ and above 20 years were significantly lower than that of the control group. The fact that in the women exposed to $\mathrm{CS}_{2}$ for 6 months and 1 year no decrements in serum $\mathrm{DBH}$ activity were found suggests that the exposure time shorter than one year may be too short to modify serum enzyme activity.

It is known ${ }^{8,9)}$ that inhaled $\mathrm{CS}_{2}$ is rapidly distributed throughout the body and 
taken up by the tissues where it reacts with free amino acids and endogenous amines resulting in its dithiocarbamate-type metabolites. The accumulation of these compounds is dependent upon: 1) the supply of free $\mathrm{CS}_{2}$ to the tissue and 2) the availability of endogenous substrates for metabolite formation. In the $\mathrm{CS}_{2}$ exposed rats McKenna and DiStefano ${ }^{8)}$ found the highest concentrations of dithiocarbamates and similar metabolites of $\mathrm{CS}_{2}$ in the adrenals, and only small amounts of these compounds in the blood and muscles. It has been thought ${ }^{9,10)}$ that dithiocarbamate metabolites of $\mathrm{CS}_{2}$ rather than the native solvent inhibit adrenal DBH activity. The mechanism of inhibition is the chelation of copperthe essential DBH cofactor, by these metabolites.

One could explain the lower serum DBH activity in the women occupationally exposed to $\mathrm{CS}_{2}$ by the deficiency in serum copper. However, this supposition is weakened by the fact that no decrease in the concentration of cupric ions in the serum of women exposed to $\mathrm{CS}_{2}$ was found (Stanosz, unpublished observation). Moreover, the decrement in DBH activity observed in the present study after addition of copper to the incubation mixture indicates a sufficient amount of copper in the serum of subjects, since it is known ${ }^{11,12)}$ that an excess of copper inhibits the enzyme activity.

It is likely that the decrease in the serum DBH activity observed in the women exposed to $\mathrm{CS}_{2}$ can be related to a diminished release of $\mathrm{DBH}$ into the blood stream from its storage sites (adrenal medulla and/or sympathetic nerve endings). Such a suggestion is in agreement with the data of Caroldi et al. ${ }^{10)}$ who reported the increased enzyme content in the adrenals in animals exposed to $\mathrm{CS}_{2}$.

In the women exposed to $\mathrm{CS}_{2}$ for 15 years the serum $\mathrm{DBH}$ activity was similar to that in the control group, thus it was higher than the enzyme activity found in the women with shorter and longer duration of the exposure (5, 10 and 20 and above 20 years, respectively). The cause for this phenomenon still remains unknown and further studies are needed to elucidate it.

\section{REFERENCES}

1) Davidson M, Feinleib M. Carbon disulfide poisoning: A review. Am Heart J 1972; 83: $100-14$.

2) Peters HA, Levine RL, Matthews CG, Sauter S, Chapman L. Synergistic neurotoxicity of carbon tetrachloride/carbon disulfide (80/20 fumigants) and other pesticides in grain storage workers. Acta Pharmacol Toxicol 1986; 59, Suppl 7: 535-46.

3) Magos L, Jarvis JAE. The effects of carbon disulphide exposure on brain catecholamines in rats. Br J Pharmacol 1970; 39: 26-33.

4) Magos L. Toxicity of carbon disulphide. Ann Occup Hyg 1972; 15: 303-9.

5) McKenna MJ, DiStefano V. Carbon disulfide. II. A proposed mechanism for the action of carbon disulfide on dopamine-beta-hydroxylase. J Pharmacol Exp Ther 1977; 202: $253-66$.

6) Caroldi S, Jarvis JAE, Magos L. In vivo inhibition of dopamine-beta-hydroxylase in rat adrenals during exposure to carbon disulphide. Arch Toxicol 1984; 55: 265-7.

7) Nagatsu T, Udenfriend S. Photometric assay of dopamine-beta-hydroxylase activity in 
human blood. Clin Chem 1972; 18: 980-3.

8) McKenna MJ, DiStefano V. Carbon disulfide. I. The metabolism of inhaled carbon disulfide in the rat. J Pharmacol Exp Ther 1977; 202: 245-52.

9) Rosier J, Veulemans H, Masschelein R, Vanhoorne M, Van Peteghem C. Experimental human exposure to carbon disulfide. II. Urinary excretion of 2-thiothiazolidine-4carboxylic acid (TTCA) during and after exposure. Int Arch Occup Environ Health 1987; 59: 243-50.

10) Caroldi S, Jarvis J, Magos L. Stimulation of dopamine-beta-hydroxylase in rat adrenals by repeated exposures to carbon disulphide. Biochem Pharmacol 1984; 33: 1933-6.

11) Nagatsu T. Dopamine-beta-hydroxylase. In: Boulton AA, Baker GB, Yu PH, eds. Neurotransmitter enzymes. Clifton, Humana Press, 1986; 79-115.

12) Orcutt JC, Molinoff PB. Endogenous inhibitors of dopamine-beta-hydroxylase in rat organs. Biochem Pharmacol 1976; 25: 1167-74.

1) Institute of Biology, N. Copernicus University,

Elżbieta WASILEWSKA ${ }^{1)}$ 87-100 Toruú, Poland

2) Institute of Gynecology and Obstetrics, Medical School, Stanislaw STANOSZ2) 70-110, Szczecin, Poland

(Received October 17, 1988 and in revised form January 27, 1989) 